\title{
Alternative Ways of Financing Civic 'Place-Based' Initiatives in Italy: A Case Study Approach
}

\author{
Veronica De Crescenzo \& Flavio Pichler \\ Department of Business Administration \\ University of Verona \\ Via Cantarane, 24, 37129 Verona \\ Italy
}

\begin{abstract}
Civic crowd funding is a tool for developing a new way of interacting between citizens and the public sector and for supporting public finance. This paper investigates the supply side of the Italian civic crowdfunding market. By using a case study approach, the paper shows the fundamental role played by local public administration in promoting, selecting and financing projects searching for funds, and for driving the successful conclusion of such projects. Matched funding schemes are crucial for a positive conclusion. The study also sheds light on the operational features and business model of the crowdfunding platforms involved in civic initiatives.
\end{abstract}

Keywords: local public administration, crowdfunding, web platforms, place-based initiatives, case study

\section{Introduction}

With the spread of social media and new technologies able to connect citizens and to act as a catalyst of public debate on specific issues, along with the increasing requirement for more transparency on public choices, the relationship between the public sector and citizens is rapidly changing. Civic crowdfunding is one of the tools for developing a new way of interacting between the public sector and citizens (Stiveret al., 2015a). Participatory budgeting initiatives, where citizens can discuss and prioritize the budget allocation of their local government, are another tool for citizen participation. Civic crowdfunding adds something more to these initiatives: it changes citizens' role from prioritising public spending to financing it (Charbit\& Desmoulins, 2017).Moreover, with increasing public sector budget constraints, civic crowdfunding is an instrumental support mechanism for public finance.Therefore, civic crowdfunding is a topic of great interest, in view of a possible new legal and regulatory regime for social and community finance investment offerings and activities (NESTA, 2011).

In the broad framework of crowdfunding, civic crowd funding can be defined as a method of collecting capital for public goods or services of public interest, in total or partial substitution for funding by the public sector itself. Crowdfunding bases its success on the capacity to bring together as many people as possible who are interested in financing a particular project. Factors that can help bring people together are geographical and relational closeness, and a specific interest in the project. Connections to, and relationships within, the community are essential for any type of crowd funding (Huiet al., 2014), but they are particularly important in the case of a civic fundraising campaign. This is what is known as the'place-based' dimension of the phenomenon (Charbit\& Desmoulins, 2017).

Moreover, the public bodies' involvement in defining the crowdfunding campaign and in contributing financially (matched funding) is one of the key factors for understanding the potential of this tool. It is particularly important to underline that according to the 'place-based' dimension of these initiatives, the public body involved is usually the local public administration.

Civic fundraising campaigns usually take place on web platforms. The operational and business models of these civic crowdfunding platforms can vary considerably. This is a fundamental aspect for understanding which elements can contribute to the success of a fundraising campaign, because different models may be more or less attractiveto the stakeholder communities involved in civic initiatives, and thus more or less supportive for fundraisers. In this context, this paper is aimed at contributing to the advancement of scientific knowledge on the structure of the civic crowdfunding market and on the role played by local public administration, with a particular regard to the Italian context. 
Furthermore, although referring to the Italian situation, this study could contribute to a better understanding of alternative ways of financing public goods or services, regardless of the legal constraints affecting public administrations' activity in different legal systems. The following research questions inspired this paper:

- Which type of platform's business and operational model should be considered relevant for the success of a civic crowdfunding round?

- What should the role of the local government be in promoting, selecting and financing the project searching for funds, and in pushing for the successful conclusion of the project?

This study is based on two approaches: 1) non-participant observation of the Italian civic crowdfunding market, to gain a complete understanding of the phenomenon; 2) the case study approach. A qualitative case study approach was selected, as the research topic is still in its infancy. The case study approach was used to analyze three unique civic crowdfunding initiatives characterized by strong engagement by different local public administrations.

The remainder of this paper is organized as follows. Sections 2 present the theoretical framework, analysing the key elements of civic fundraising; Section 3 presents the methodological aspects of the research. Section 4 focuses on the empirical evidence emerging from the analysis. Section 5 presents the discussion, and Section 6 consists of the main conclusions and research limitations, describes the policy implications and identifies an agenda for future research paths.

\section{Civic crowdfunding's theoretical framework: The key factors for civic fundraising process}

In the context of economic and financial crisis, the topic of innovative financial instruments, such as crowd funding, has been gradually gaining increasing attention by researchers. However, academic research into civic crowd funding is in the early stages of development, even if the potential of civic crowdfunding for boosting economic outcomes and realising a more democratic, transparent and efficient allocation of financial resources has been underlined (Passeri, 2017).

The first element that must be clarified is when a crowdfunding campaign can be considered civic. For this to be the case, the initiatives must be aimed at improving the community's wellbeing. Consequently, the objects of civic crowdfunding campaigns are usually for the pure public good (non-excludable and non-rival use, consumption and enjoyment), club good (excludable but non-rival),or common good (non-excludable but rival) (Hardin, 1968;Ostrom, 1990; Davies, 2015; Hudik \& Chovanculiak, 2017). Moreover, these are local public goods (i.e., public goods that benefit only the geographical community of people where they are located) (Charbit\& Desmoulins, 2017). As a consequence, many different types of projects can be financed by civic crowdfunding, ranging from physical structures to public services, even though not all public goods can reasonably be the object of civic crowdfunding campaigns. Indeed, the realisation of public services and structures of primary importance, such as education, health and defence, should always be guaranteed by public finance (Migliettaet al., 2013;Hudik \& Chovanculiak, 2017). Cultural and social initiatives, and more generally the non-profit sector, have been considered the typical object of civic crowdfunding rounds. In this context, civic crowdfunding is considered to be a new tool to foster social innovation and the development of new ideas that meet social needs and create new relationships or collaborations among citizens, local public bodies, firms and non-profit organizations (Bernardino \& Santos, 2016).

Of equal importance for delimiting the phenomenon of civic crowdfunding is a lack of public money to fulfil the proposed initiatives. The degree of involvement of public bodies in defining a crowdfunding campaign, in selecting the initiatives to be funded, and in contributing financially to them represents a key element for the understanding of the potential of this new fundraising channel. First, the public body might(or might not)have a role as a proponent of the initiative to be funded. Indeed, the campaign's proponents may be: civil society organizations, citizens and the public sector. If the proponent of a fundraising campaign is the public sector without active participation from civil society organizations and citizens, the crowdfunding campaign is defined as public (Lee et al., 2016, p. 4). Then, the public body might or might not have a role as a selector of the initiative to be funded. Finally, the public body might or might not have a role as a co-funder.

Starting from the framework proposed by Davis (2014) and then by Charbit and Desmoulin (2017), and according to the role played by the public body, different approaches to public sector involvement are proposed. Without claiming to cover the great variability that characterizes this phenomenon, four models can be designed: the sponsor model, the public model, the curator model and the facilitator model. 
In the sponsor model the local public administration, using a specialised civic crowdfunding platform, selects and proposes initiatives to be funded. The co-funding role may or may not be present. If the local public administrator proposes and contributes to finance the initiative, the model can be defined as public.

In the curator model, the local public administration, using a generic reward crowdfunding platform with a special exclusive civic section, selects and proposes initiatives to be funded. The co-funding role may or may not be present.

In the facilitator model, by using a specialised civic crowdfunding platform citizens propose the initiatives to be funded. The local public administration assumes the role of selector and co-funder.

When there are many potential competing civic projects seeking funds, a valuable way to select the initiatives to be screened and then posted on the platform is crowdvoting. With crowdvoting, the crowd (local community) is generally asked to formulate or express an opinion or an evaluation, or to vote on a formulated question. In this case, rather than employing a top-down procedure in which the proponent decides the funding priority, a bottomup procedure that exploits the 'wisdom of the crowd' (Mollick \& Nanda, 2016; Surowiecki, 2004) is employed (Migliettaet al., 2013). Crowdvoting could also be considered as a possible solution to the coordination problem. This may arise when the multiplicity of projects offered on a crowdfunding platform causes the inefficient distribution of donations across them, possibly leading to project failure and discouraging potential donors (Ansinket al., 2017).

The last feature to be considered with reference to the public sector's role is the timing of co-funding. The public body can decide the amount of the co-funding before or after the crowdfunding campaign. Public co-funding before the crowdfunding round signals the local public administration's strong commitment. The public body must decide the amount it wants to invest before the beginning of the crowdfunding campaign, usually expressing it as a percentage of the total amount required by the initiatives. If co-funding takes place after the crowdfunding round, the public local administration acts as a 'lender of last resort' and this implies a financial commitment by the public body that is non-programmable and highly dependent on the success of the round.

For understanding civic crowdfunding, its 'place-based' nature must finally be taken into consideration. That means that civic crowdfunding relies mainly on offline communities and contributes to concrete local impact (Charbit\& Desmoulins, 2017). Citizens who act to support the social and cultural development of an area are likely to feel motivated to participate in a civic crowdfunding campaign to fund projects of public interest aimed at improving their wellbeing (De Falcoet al., 2015).

The community that is going to support a civic round is made by the people linked by geographical closeness (geographical community) and by those linked by a special interest in a specific project (relational community) (McMillan \&Chavis, 1986). The second is wider than the first: while the geographical community is made by local inhabitants, the relational community could encompass the participation of civil society organizations, firms and non-resident supporters if the project to be financed has the potential to attract wide interest (Stiveret al., 2015a). From this perspective, funders can be divided into those who fund and enjoy the benefits of a project (individual self-interest) and those motivated by a broader interest in financing a good or service, despite not having the opportunity to enjoy the benefits directly for reasons of geographical location (self-and-others interest) (Stiveret al., 2015b). These features determine civic capacity; that is, the community's capacity to implement and financially sustain collective actions to achieve common objectives (Briggs de Souza, 2008).

The place-based nature of crowdfunding is therefore worthy of deeper study, particularly in the field of civic crowdfunding and concerning the relationship between online and offline communities. Online communities do not seem to increase or decrease communities already formed offline, but simply represent a different mode of interaction that facilitates and supports the development of pre-existing relationships (Stiver et al., 2015a). Communities that are geographically bound tend to form offline, continuing and strengthening existing relationships online. This means that people who interact online usually know each other in a face-to-face context, or if they have not met already, they expect that they may meet in the future.

Community involvement in a fundraising campaign can also be measured by the intensity with which the community interacts online in exchanging information and knowledge. Exchange and sharing of information and experience among the members of a community online is also influenced by the extent to which community members know each other, by perceived similarity with the other members of the community, and by trust in the other members of the community (Zhao et al., 2012). 
In this context there are two elements that need to be analyzed in depth: how platforms interpret the place-based dimension of the civic fundraising process, and how platforms help to strengthen relationships among people belonging to the community. These features will be taken into consideration in the following analysis of the business and operational model of the platforms.

\section{Research methods}

This research study is based on two approaches: 1) non-participant observation of the Italian civic crowdfunding market, to gain a complete understanding of the phenomenon; 2) a case study approach. Non-participant observation helped us in two ways: to identify the business and operating models of the Italian platforms that have managed civic fundraising campaigns, and to select the case studies.

Based on the information provided by the website http://italiancrowdfunding.it, we identified a list of the Italian reward and donation platforms existing in January 2017 (about 70 platforms). In accordance with the aims of civic crowdfunding, it is plausible to consider that donation and reward platforms are most suited to this type of campaign because these models share the motivations that usually prompt people to finance a project (sense of belonging, moral recognition and ethical value). Through desk-based research on the websites of these platforms and by employing the criterion of the presence of a collective benefit from relevant projects (improving a community's wellbeing), a subset of 25 platforms was recruited. The list of these 25 platforms is shown in Table 1 .

Table 1: List of Italian reward and donation platforms involved in civic crowdfunding campaigns (January 2017)

\begin{tabular}{ll} 
& Name of Platform \\
\hline AnciInnovazione & Kendoo \\
Buonacausa & Mecenup \\
Civibanca & Meridonare \\
Com-unity & Planbee \\
Derev & Produzioni dal basso \\
Eppela & Proposizione \\
Eticarim & Replace \\
Fidalo & Rete del dono \\
Finanziamiiltuo futuro & Schoolraising \\
FundItaly & TerzoValore \\
Ginger & Ulule \\
Insiemedoniamo & With you we do \\
Iodono & \\
\hline
\end{tabular}

For data collection on the 25 platforms, sections of the platforms' websites were used: 'About us', 'How it works' and 'Frequently asked questions (FAQs)'.

Based on the models described in Section 2 (the sponsor, public, curator and facilitator models) and by adding other variables referring to the platform's business and operational model, the civic supply side Italian market is analyzed. These additional variables are: platform specialisation (generic or dedicated civic platform); platform's territorial specialisation; presence of rewards; request for donations in kind; how projects are presented in relation to videos and/or images; availability of platform-supported conversations between fundraisers and funders/community (e.g., forums and comments); links to social networks; and use of crowdvoting.

Civic crowdfunding campaigns can use either generic platforms, which may or may not have dedicated civic sections, or specialized civic crowdfunding platforms. For the purposes of this paper, the concept of territorial specialisation can be understood either formally (obligation of the fundraisers to be resident in a certain area) or substantially (the projects to be financed have repercussions in that area). The decision of the platform to limit its operations to a certain geographical area is expected to be more common for specialized civic crowdfunding platforms compared to generic platforms. 
The presence of a reward for the funders should be a minor element for the success of the campaign because in civic crowdfunding campaigns the principal return for funders consists of moral recognition, a sense of belonging to the community, and, above all, the possibility of enjoying the good or service proposed. As a form of reward, returns from civic crowdfunding tend not to be tangible or have monetary value, but usually consist of acknowledgement (e.g., a thankyou email) (Stiveret al., 2015b).

The request for donations in kind (material or immaterial, such as offering hours of work) is a further element distinguishing civic fundraising from the generic fundraising typical of reward platforms, and such elements can further strengthen community bonds, even after the conclusion of the fundraising campaign (Stiveret al., 2015a).

Platform features, including space on the platform website for conversations among funders and direct connections with the main social networks, are elements that promote community relationships. The presence of forums or virtual spaces where two-way communication can occur between proponents of the initiative and the sustaining community is particularly significant. The two main activities conducted online by stakeholders arethe collection and broadcasting of information and the coordination of activities to sustain the initiative (Stiveret al., 2015a).

Finally, the spread of the practice of crowdvoting in civic crowdfunding campaigns may be a way the community prioritises the projects to be funded by using a bottom-up criterion. Starting from the results of the supply side market's analysis, some case studies of civic crowdfunding initiatives were selected. These were the civic crowdfunding initiatives promoted by i) the City of Milan, ii) the Municipality of Capannori, and iii) the Region 'Piemonte' on the Eppela platform. These casestudies present unique features in the Italian civic crowdfunding market and have the potential to allow us to explore our research questions in depth.

Given the fact that the research topic is relatively new and that more research is needed to properly understand it, a qualitative casestudy approach was selected (Yin, 2003). As recognised by Eisenhardt (Eisenhardt, 1989; Eisenhardt \& Graebner, 2007), the study of one or more cases is useful to develop theories on specific topics.

In order to corroborate the credibility of the study (Lincoln \& Guba, 1985), data and information have been collected from different sources and then triangulated (Yin, 2003; Gibbertet al., 2008; Miles \& Huberman, 1994). The aim is to address potential problems of construct validity and limit personal and methodological biases through the use of multiple sources of evidence that essentially provide multiple measures of the same phenomenon.

\section{Empirical evidence from the Italian civic crowdfunding market}

\subsection{The supply-side market: Platform business and operating models}

The Italian civic crowdfunding market is characterized by two features that influence the whole structure: first, the reward model tends to predominate, while pure donation platforms involved in civic rounds are a minority; second, the involvement of the local public administration as proponents and/or co-funders is not common. Indeed, civic initiatives are usually promoted on crowdfunding platforms directly by citizens or by civil society organizations and are financed without a public matched funding scheme.

When considering the 25 platforms listed in Table 1, there are only three cases in which the local public administration played a role as proponent, selector or co-funder. When classified according to the models described in Section 2 we found one case of the sponsor model, one case of the public model, and one case of the curator model. All were reward platforms, and territorial specialisation was only required by the public model. None sought donations in kind or used a crowdvoting process. It is interesting to underline that the curator model, in contrast to the other two models, was based on a generic reward platform, and the use of images, videos, links to social networks and virtual space for conversation seemed to be a more consolidated practice in this case.

An active role for the local public administrations was not provided by the other 22 platforms involved in civic crowdfunding campaigns. For these platforms, there did not seem to be a relationship between the specialisation of platforms for civic fundraising campaigns and territorial specialisation. Therefore, platforms that claim to limit their activity to a particular geographical location are both generic platforms with reward models and social platforms with donation models. A request for donations in kind by the project fundraiser is rarely used in the Italian civic crowdfunding market, and when it is, it accompanies, rather than replaces, monetary donations and involves work time. This time is used to advertise and promote the crowdfunding campaign or to provide professional consultancy to the project's fundraiser. 
As far as the use of images, videos, links to social networks and virtual space for conversation is concerned, there is a uniformity of behaviour for generic platforms. It seems as if the experience gained by these platforms in their reward campaigns has been adopted without significant changes in the operating models for civic crowdfunding rounds. Instead, the four platforms dedicated exclusively to civic crowdfunding revealed a much more differentiated configuration. Some did not provide videos or direct links to social networks, while others did not offer spaces dedicated to forums or comments. Less attention to visualisation, communication, promotion and sharing of the crowdfunding campaign seems to emerge for this type of platforms.

Crowdvoting was rarely used, and was not used to rank projects, but rather, to improve the visibility of single projects on the platform website (the underlying idea is that better visibility might improve the probability of the success of a crowdfunding round).

Next, case studies were chosen on this basis of this initial research. We decided to focus on the curator model because it is the unique case in Italy that allows us the possibility of analyzing the local public administrations' role in defining, selecting and financing civic crowdfunding initiatives in greater depth. The local public administrations responsible for the civic crowdfunding initiatives promoted on the Eppela platform (a generic reward platform) are i) the City of Milan, ii) the Municipality of Capannori, and iii) the Piemonte Region.

\subsection{Three local public administrations' civic initiatives promoted on a generic reward platform}

The three local public administrations listed above (two municipalities and one region) launched their civic initiatives on Eppela, a generic reward crowdfunding platform with a special dedicated civic section.

Using documents made available on the platform's website and on the local government's website as data sources for each case, the following elements were considered: the aim of the initiative, the timing of the initiative, the role played by the local public administration, and the results gained. It is important to underline two aspects: two of the selected initiatives are already closed, while one is still open; the dimensions of the local public administrations vary considerably and this can affect the initiative's budget.

The City of Milan started its trial initiative (lasting 18 months, from December 2015 to June 2017) with the aim of promoting more effective involvement of citizens in the funding decision processes of the local government. It defined a number of areas of interest which the selected projects must have an impact on, mainly related to the introduction of technological devices for urban connectivity; reduction of the digital gap for both citizens and firms; improvement of quality of life through the fulfilment of cultural activities; innovation in care services and the development of social and community networks. The City is not the proponent of the projects, but selects the projects to be posted on the Eppela website. It created a call for projects open to both for-profit and civic society organizations, and the projects selected by the City of Milan were posted on Eppela to raise the funds they required. The budget required by each projects ranged between 6,500-100,000 euro, with a median of 35,000 euro. The City of Milan also acted as a co-funder, guaranteeing co-funding only if the platform's funding round managed to raise 50 per cent of the total amount of funds needed through the crowd's contributions. Moreover, each project had to be funded by at least 30 backers, who were not permitted to be family members with first or second degree kinship to the proponent of the project. At the end of all the funding rounds on Eppela, 16 of the 18 projects posted on the platform were successfully closed. The total amount raised from the funding rounds consisted of approximately 300,000 euros. The same amount was guaranteed by public co-funding; therefore, the final investment in the City of Milan's territory was approximately 660,000 euros.

The Municipality of Capannori (a small town in Tuscany) launched its initiative at the end of 2016 with the aim of promoting new entrepreneurial initiatives able to foster social, economic and work-related wellbeing within the region. The Municipality defined several areas of interest that projects to be funded must insist on: innovative craftsmanship, reuse and the circular economy, sharing economy, new technologies and agriculture. The local public administration acted as the selector. Only five circular economy-based projects were selected and posted on Eppela (from September to November 2017). They required amounts of funds ranging from 6,000 to 10,000 euros. The Municipality acted as a co-funder by guaranteeing co-funding only if the platform's funding round managed to raise 50 per cent of the total amount of funds required through crowd contributions. All five projects posted on the platform were successfully closed. The total amount raised from the funding rounds consisted of 40,000 euros, while the local public administration co-financed them with a further 20,000 euros. The initiative of the Piemonte Region is still open. It was launched at the end of 2017 and will close by October 2018, through a schedule planning process based on different phases (two of which are already closed). 
The aim of the initiative is to promote cultural activities in the geographical area: investments in goods and equipment, and restoration and structural interventions for the recovery or preservation of buildings of historical and artistic value andplaces of cultural activities (such as museums, theatres, libraries). The call is open to both for-profit and civic society organizations. It requires that each project has a budget of a minimum of 20,000 euros and this budget must be financed through the crowdfunding round for 10,000 euros. As before, the local public administration is not the proponent, but acts as the selector of the projects to be posted on Eppela's website. Public co-funding is not planned in this case. To date (end of March 2018), only three projects have been posted on the Eppela website with the 'all-or-nothing' method of raising funds. The deadline for these projects has expired and none were successfully closed because they did not reach the target amount they required.

\section{Discussion}

The generic reward crowdfunding platforms appear to be the key players in the Italian civic crowdfunding market. The business and operating model of this type of platform is a consolidated one that does not present substantial differences between civic and non-civic fundraising campaigns. The first aspect to consider for Italian civic crowdfunding is therefore the lack of a specialised supply side market. Unlike the US and the UK (Charbit\& Desmoulins, 2017), the Italian civic crowdfunding market appears to have developed primarily through a process of related diversification of the reward-donation model, rather than through the emergence of a new and independent crowdfunding model. Consequently, the Italian civic crowdfunding market reveals room for improvement in adjusting the services offered to the needs of both fundraisers and funders.

The case studies analyzed allow for better investigation of this emergent phenomenon. Eppela represents one of the key players in the Italian civic crowdfunding market. To date, this is the only Italian platform through which civic crowdfunding initiatives have been successfully promoted in cooperation with local public administrations. The case studies presented here, as the first partnership between a crowdfunding platform and local governments in Italy, are therefore particularly useful to enable us to understand fundraising for public goods or services of public interest in partial substitution for local government financing and within a specific institutional/legal framework and an evolving context.

The analysis of these initiatives has demonstrated that civic crowdfunding can be used to finance different types of projects, from entrepreneurial businesses aimed to develop technological devices to cultural activities, as well as restoration interventions for the recovery or preservation of important areas or buildings. Evidently, these different types of projects also imply the necessity for different amount of funding.

The analysis also points out another important feature: the presence of local public administration of different standing in the Italian civic crowdfunding market. It is particularly interesting to highlight that the two successful initiatives were promoted by municipalities not comparable in terms of dimensions.

The three initiatives analyzed revealed some commonalities, but also some differentiating elements. The local public administrations involved in these initiatives always assumed the role of selector. The municipality's role in the selection of projects is partly connected to the relevant legislative framework, which stipulates that public bodies must act when the expenditure of public money is involved (e.g., public procurement procedures). Further, selection by the public body may have a positive effect by allowing re-balancing of the public interests proposed by different projects, with the municipality correcting potential inequalities among the various areas of its territory.

Another interesting element emerges with reference to the proponent. Indeed, only for-profit and civil society organizations can be proponents of these projects. Citizens are not given the opportunity to become proponents. This decision may be considered only partially in line with the typical civic crowdfunding scheme.

To conclude, the role of the local public administrations as co-funders seems to assume critical importance for the successful conclusion of these initiatives. The initiatives sponsored by the City of Milan and the Municipality of Capannori, all successfully closed, were based on matched funding between the crowd and the local public administration. This matched funding was calculated as a percentage of the total budget required by the initiative and it is ensured only if the crowdfunding campaign has been successfully concluded. To date, no public matched funding has been made available for the Piemonte Region's initiative; however, due to the fact that this initiative is not finished, any conclusions should be premature. Nevertheless, it must be highlighted that the initiative is currently having difficulty in reaching the minimum target amount from crowd investors. 


\section{Final Remarks}

Civic crowdfunding is still an emerging phenomenon, but its growth path makes it an effective alternative tool for both developing a new way of interacting between citizens and the public sector, as well as for supporting public finance.

Our paper contributes to the existing scientific literature on civic crowdfunding in two ways: on the one hand by analyzing the business model operating features of the crowdfunding platforms, and on the other, by analyzing the role played by local governments in an evolving market. To our knowledge, this paper represents the first systematic analysis of the business models and operating features of the Italian crowdfunding platforms involved in civic fundraising campaigns. Therefore, the study contributes to a better understanding of an emerging and under-researched phenomenon, and represents a first step in understanding the crucial elements that may contribute to the success of civic crowdfunding.

Although further case studies are needed to evaluate our research questions more accurately, certain operational features of the process, and the outstanding role of the local public administrations that emerged from the casestudy analysis are elements to be considered carefully.

First, the Italian civic crowdfunding market reveals room for improvement in adjusting the services offered by specialised platforms to the needs of both fundraisers and funders.

Second, local public administrations' will to contribute to the funding process is an important incentive to the success of such projects in an 'all-or-nothing' framework. Civic crowdfunding growth arises in a context in which regional and local authorities, which historically have served as a link between citizens and national institutions, are best positioned to foster private investments, address local needs and develop inclusive and democratic financing models.

The fact that only organizations (either for- or not-for-profit), and not citizens, are allowed to submit projects has various implications. On the one hand, the number of projects is smaller, thus facilitating the selection process by the public partner, particularly at an early experimental stage. Conversely, projects developed by structured organizations settled in the area might be perceived as more reliable and more valuable. The proponents themselves may also benefit from reputational rewards, showing their commitment to the public good in the relevant area.

Using a casestudy approach can limit the investigation of further critical aspects of the phenomenon. First, the motivations for,and the deterrents from, supporting a civic crowdfunding campaign are other aspects to examine in greater depth. This analysis may be achievedthrough either interviewing funders or analysing the content of comments posted on platform websites by funders or people interested in the campaign. Then, analogouslytoprior research into other types of crowdfunding models (e.g., reward, peer-to-peer lending and equity), civic crowdfunding campaigns, both funded and non-funded, need to be analyzed to identify which features are fundamental to the success of a civic crowdfunding campaign.

Understanding the features and dynamics that underpin civic crowdfunding is anextremely interestingtopic for further research and it is important for policymakers (who decide on regulatory issues), public bodies and crowdfunding platforms. For policymakers and public bodies, it is important to underline that civic crowdfunding is a useful tool to facilitate more effective identification of goods and services of public interest that are perceived as important to the community, and a means to achievethe modification of funding schemes. Future research should examine the ability of civic crowdfunding to act on,and improve, local democracy and social equity.

A greater understanding of the phenomenon is also important for the crowdfunding platforms themselves to develop services for proponents and fundraisers that facilitate the success of fundraising campaigns, the online and offline relationships among community members and the realisation of the projects seeking funds.

\section{References}

Ansink, E., Koetse M., Bouma J., Hauck D., van Soest D. (2017).Crowdfunding Public Goods: An Experiment. Tinbergen Institute Discussion Paper, TI 2017-119/VIII.

Bernardino, S.J., Santos, J.F. (2016).Potential of Civic Crowdfunding to the Intelligence of Cities and Social Innovation: An Exploratory Study.Proceedings of the Portuguese Association for Information Systems Conference. http://dx.doi.org/10.18803/capsi.v16.311-323. 
Briggs de Souza, X. (2008).Democracy as problem solving: Civic capacity in communities across the globe. MIT Press.

Charbit, C., Desmoulins, G. (2017).Civic Crowdfunding: A Collective Option for Local Public Good?.OECD Working Paper, 2017/02.

Davies, R. (2014).Civic crowdfunding: Participatory communities, entrepreneurs and the political economy of place. Massachusetts Institute of Technology.

Davies, R. (2015). Three provocations for civic crowdfunding.Information, Communication \& Society, 18, 3, 342-55.

De Falco, S., Volpe, E., Cucari, N. (2015).Civic crowdfunding e valore del territorio: un'analisi empirica attraverso due piattaforme italiane. Economia e diritto del terziario, 1, 675-92.

Eisenhardt K.M. (1989).Building theories from case study research.Academy of Management Review, 14, 4,532550.

Eisenhardt, K.M., Graebner, M.E. (2007). Theory building from cases: opportunities and challenges. Academy of Management Review, 50,1, 25-32.

Gibbert M., Ruigrok W., Wick B. (2008). What passes as a rigorous case study?.Strategic Management Journal, $29,1465-1474$.

Hardin, G. (1968). The tragedy of commons.Science, 162, 3859, 1243-1248.

Hudik, M., Chovanculiak, R. (2017). Private provision of public goods via crowdfunding.Journal of Institutional Economics, doi:10.1017/S1744137417000169.

Hui, J.S., Greenberg, M.D., Gerber, E.M. (2014).Understanding the Role of Community in Crowdfunding Work.Proceedings of the $17^{\text {th }}$ ACM Conference on Computer Supported Cooperative Work and Social Computing.

Lee, C.H., Zhao, J.L., Hassna, G. (2016). Government-incentivized crowdfunding for one-belt, one-road enterprises: Design and research issues.Financial Innovation, 2,2, 1-14.

Lincoln, Y. S., Guba, E. G. (1985).NaturalisticInquiry.SAGE.

McMillan, D.W., Chavis, D.M. (1986). Sense of community: a definition and theory.Journal of Community Psychology, 14, 1, 6-23.

Miglietta, M., Parisi, E., Pessione, M., Servato, F. (2013).Crowdfunding and Local Governments: A Financial Opportunity for a New Liaison with Citizens.Conference proceedings of the $16^{\text {th }}$ Toulon-Verona Conference 'Excellence in Services'.

Miles, R., Huberman A. M., (1994).Qualitative Data Analysis: An Expanded Sourcebook. SAGE Publications.

Mollick, E., Nanda, P. (2016). Wisdom or madness? Comparing crowds with expert evaluation in funding the arts.Management Science, 62, 6,1533-1553.

NESTA (2011).Investing in Civil Society: A Framework for a Bespoke Regulatory Regime.NESTA Policy Paper.

Ostrom, E. (1990).Governing the Commons: The Evolution of Institutions for Collective Action.Cambridge University Press.

Passeri F. (2017).The European Dimension of Civic Crowdfunding.European Crowdfunding Network Paper, http://eurocrowd.org/.

Stiver, A., Barroca, L., Petre, M., Richards, M., Roberts, D. (2015a).Civic Crowdfunding: How do Offline Communities Engage Online?.Proceedings of the British Human-Computer Interaction Conference.

Stiver, A., Barroca, L., Minocha, S., Richards, M., Roberts, D. (2015b), Civic crowdfunding research: Challenges, opportunities, and future agenda.New Media \& Society, 17, 2, 249-271.

Surowiecki, J. (2004).The Wisdom of Crowds: Why the Many are Smarter and How Collective Wisdom Shapes Business, Economies, Societies and Nations.Random House.

Yin R.K. (2003).Case Study Research. SAGE Publications.

Zhao, L., Lu, Y., Wang, B., Chau, P.Y., Zhang, L. (2012). Cultivating the sense of belonging and motivating user participation in virtual communities: A social capital perspective.International Journal of Information Management, 32,6, 574-588. 